УДК 341.231.145

DOI https://doi.org/10.32837/pyuv.v0i1(30).511

\author{
К.В. Громовенко \\ orcid.org/0000-0002-9466-8575 \\ кандидат юридичних наук, ректор \\ Міжнародного гуманітарного університету
}

\title{
ПРАВО НА ВИЩУ ОСВІТУ В ДІЯЛЬНОСТІ ОРГАНІЗАЦІЇ З БЕЗПЕКИ ТА СПІВРОБІТНИЦТВА В ЕВРОПІ
}

Дослідження міжнародних стандартів права на вищу освіту сьогодні залишається вкрай важливим питанням вітчизняної правової доктрини. Такий аналіз не може бути повним без вивчення відповідної практики Організації безпеки та співробітництва в Європі (ОБСЄ), яка наразі грає одну з провідних ролей у забезпеченні прав людини, регіональної безпеки та міждержавного співробітництва. Хоча аспектам діяльності ОБСЄ у вимірі прав людини було приділено значну увагу в працях сучасних вітчизняних дослідників, таких як Т.В. Анцупова, Б.В. Бабін, М.О. Баймуратов, М.В. Буроменський, О.О. Гріненко та інші, відповідна робота організації з питань освіти предметом наукових досліджень не стала. Отже, станом на сьогодні величезну актуальність має питання визначення змісту наднаціональних стандартів щодо вищої освіти в практиці ОБСЕ, що є метою цього дослідження. До його завдань слід віднести аналіз діяльності ключових інституцій ОБСЄ у вимірі вищої освіти та права на освіту, наявних документів та досліджень організації, практики надання освітніх послуг установами під егідою ОБСЄ.

ОБСЄ як організація виникла внаслідок проведення серії Нарад з безпеки та співробітництва між демократичними та прорадянськими країнами. Питання освіти відображалися вже у першому потужному документі зазначених процесів, Заключному акті Наради з безпеки та співробітництва в Європі від 1 серпня 1975 р. У розділі Акту «Співпраця та обміни в галузі освіти» визнавалося, що розвиток «відносин міжнародного характеру в галузі освіти сприяє кращому взаєморозумінню, є корисним всім народам та благотворним для прийдешніх поколінь», вказувалося на важливість обміну знаннями та досвідом, організації контактів між установами та діячами освіти. Також у Акті відзначалася потреба зміцнювати зв'язки, заохочувати співпрацю між навчальними закладами, з поширенням знання іноземних мов [3].

У рамках розширення зв'язків Акт $1975 \mathrm{p}$. вказував на необхідність встановлення як безпосередніх домовленостей між університетами та іншими вищими навчальними закладами, так і на доцільність укладання міжурядових угод, відзначав корисність обмінів студентів, викладачів і науковців та потребу його заохочення. Зокрема, це стосувалося:
- розширення обміну інформацією про можливості навчання та спеціальностей, відкритих для іноземних учасників, про умови їх прийому та перебування;

- сприяння поїздкам студентів та викладачів з одних держав в інші для навчання, викладання й кращого ознайомлення з досягненнями освіти;

- заохочення надання студентам та викладачам інших держав стипендій для навчання, викладання або проведення наукової роботи;

- розробки, розвитку чи заохочення програм широкого обміну студентами та викладачами, включаючи організацію симпозіумів, семінарів, спільних проектів, обмін навчальною та науковою інформацією, включно із університетськими виданнями та бібліотечними матеріалами;

- забезпечення можливості іноземним студентам та викладачам в рамках обміну користуватися відповідними навчальними, науковими і відкритими архівними матеріалами; сприяння їх поїздкам у приймаючи держави в навчальних, наукових цілях та в формі канікулярних турів;

- поглиблення аналізу порівнянності й еквівалентності ступенів та дипломів через заохочення обміну інформацією щодо умов навчання, порівняння методів оцінки знань й кваліфікації [3].

Додатково Акт 1975 р. приписував держави звернутися до власних університетів із пропозицією повніше і регулярніше обмінюватися інформацією щодо їх нинішніх та прогнозованих досліджень, здійснювати координацію програм та організацію спільних програм, зокрема, в сектоpax точних та природничих наук, медицини, гуманітарних й соціальних наук.

Окрему увагу в Акті 1975 р. було приділено питанням сприяння вивченню іноземних мов і цивілізацій як «важливого засобу для розширення спілкування між народами, для їх кращого ознайомлення 3 культурою кожної країни, а також для зміцнення міжнародного співробітництва». Для цього держави мали забезпечити розвиток й поліпшення навчання іноземним мовам та різноманітність їх вибору на різних рівнях навчання, «звертаючи належну увагу на менш поширені мови». Також відзначалася важливість «проведення на двосторонній або багатосторонній основі досліджень нових методів навчання іноземних мов», зокрема, порівняльних досліджень, обмінів 
чи передачі аудіовізуальних матеріалів, матеріалів для підручників, інформації про нові типи технічної апаратури для навчання мовам [3].

Наступні акти Нарад, зокрема п. 34 Документу Копенгагенської наради Конференції з питань людського виміру, також згадували про освітній вимір. Пізніше Віденська декларація та Програма дій ОБСС від 25 червня 1993 р. підкреслили важливість включення питання про права людини в навчальні програми. У Програмі вказувалося, що система освіти має сприяти взаєморозумінню, терпимості, миру та підтриманню дружніх відносин між народами й усіма расовими або релігійними групами, заохочувати діяльність ООН в інтересах досягнення цих цілей. Додавалося, що навчання в сфері прав людини має включати питання забезпечення миру, демократії, розвитку та соціальної справедливості, як про це йдеться в міжнародних та регіональних договорах з прав людини, з метою досягнення загального розуміння та обізнаності для зміцнення універсальної прихильності правам людини (п. 33, п. 80 Програми) [1].

Наразі питання освіти у ОБСЄ опрацьовуються у декількох вимірах, це захист освітніх прав меншин, освіта й права людини та освіта в умовах конфлікту. Офіційно ОБСС повідомляе, що «освітні програми є невіддільною частиною зусиль ОБСЄ із запобігання конфліктам та постконфліктного відновлення». До цього додається, що «викладачі відіграють центральну роль у формуванні поведінки і поглядів людей, з якими вони працюють в суспільстві» [6]. При цьому, керуючись своїм мандатом щодо запобігання конфліктів, Верховний комісар ОБСЕ у справах національних меншин (далі - ВКНМ) взаємодіє з державами стосовно національної політики освіти меншин, у пошуку «балансу між збереженням ідентичності та забезпечення згуртованості багатонаціональних співтовариств», «міжетнічного взаєморозуміння і взаємодії в процесі навчання», "висвітлення різних поглядів під час викладання історії». Інша інституція ОБСЄ - Бюро з демократичних інститутів і прав людини ОБСЄ (далі - БДІПЛ), має на меті забезпечення поваги різноманітності і взаєморозуміння під час освіти та забезпечення освіти у сфері прав людини. Ряд польових операцій ОБСЄ приділяють увагу освітнім питанням щодо реформ системи освіти, включаючи юридичну освіту, визначення результатів і стандартів навчання, усунення дискримінації та відчуження під час освіти [6].

У рамках діяльності ВКНМ у 1995-1996 роках було опрацьоване Гаазькі рекомендації щодо прав національних меншин на освіту і Пояснювальну записку до них. Цей документ готувався під патронатом ВКНМ Фундацією міжнаціональних відносин, що залучила як юристів-міжнародників, так й лінгвістів та освітян, що спеціалізуються на питаннях становища і потреб меншин, які, зокрема, представляли Стратклідський університет (Великобританія), Норвезький інститут прав людини, Кінгз коледж (Великобританія), Університет Або Академія (Фінляндія), Університет Роскільд (Данія), Університет Янус Панноніус (Угорщина), Кільський університет (Німеччина) та Національний інститут з питань розвитку методів навчання (Нідерланди) [2].

Гаазькі рекомендації приписували під час організації освіти меншин, зокрема й вищої, враховувати «дух міжнародно-правових актів», права меншин на самобутність, принципи рівноправності та відсутності дискримінації, неприпустимість обмежувального тлумачення міжнародних зобов'язань у сфері освіти меншин. Для ефективного забезпечення освіти меншин державам приписувалося для забезпечення прав на навчання мовою меншин застосовувати як наявні ресурси, так й міжнародну допомогу, економічне і технічне співробітництво. Також цим документом ОБСЄ державам приписувалося надати можливість інституціям, які представляють меншини, повноцінно брати участь у розвитку та впровадженні політики і програм щодо їх освіти, а також наділити повноваженнями у цій сфері регіональні та місцеві органи влади [2].

Також у Гаазьких рекомендаціях визнається право осіб, що належать до національних меншин, засновувати свої власні приватні освітні заклади та управляти ними відповідно до внутрішнього законодавства. До цього робиться спеціальне застереження, що держави не мають чинити перешкод у користуванні цим правом, встановлюючи занадто високі правові та адміністративні вимоги до заснування цих закладів і управління ними. Також у рекомендаціях відзначається, що приватні заклади, в яких навчання провадиться мовою меншини, мають право вишукувати свої власні джерела фінансування з бюджету, міжнародних джерел та приватного сектора, без жодних обмежень або дискримінації [2].

Крім того, у п. 17 Гаазьких рекомендацій вказано, що особи, які належать до національних меншин, повинні мати доступ до вищої освіти рідною мовою «тоді, коли вони продемонстрували в цьому потребу та коли це підтверджено їх достатньою кількістю». Для цього рекомендації приписують утворити законодавчу базу, що забезпечувала б меншини можливістю здобувати вищу освіту рідною мовою, утворюючи при цьому необхідні умови в існуючих освітніх закладах, якщо це відповідає потребам меншин. Також цей пункт дозволяє особам, що належать до таких меншин, «також вишукувати способи та засоби створення своїх власних освітніх закладів вищого рівня». Крім того, п. 17 рекомендацій приписує ураховувати під час опрацювання освітньої та мовної політики щодо меншин те, чи підтримувала за останній період 
свої вищі навчальні заклади відповідна меншина та чи здійснювала вона контроль за ними [2].

Варто вказати, що ВКНМ розвинув активну діяльність із реалізації Гаазьких рекомендацій, зокрема, в рамках проведення семінару «Інтегруючи різноманіття вищої освіти» у 2000 р. в Університеті Бабеш-Боляї в Клуж-Напоці, Румунія. Одною з цікавих форм такої роботи ВКНМ К.Р. Екеуса стало сприяння виданню у 2004 р. за співпраці з Європейською асоціацією освітнього права та політики часопису «Міжнародний журнал освітнього права та політики» [12].

Варто відзначити роль БДІПЛ ОБСЕ у формуванні освітніх стандартів, яка серед іншого відбувається шляхом складання та оприлюднення відповідних методичних матеріалів. На відміну від BКНМ, вони мають на меті встановлення освітніх стандартів щодо протидії мові ненависті та дискримінації вразливих груп, а також підвищення обізнаності у сфері прав людини. У цьому вимірі слід вказати на дослідження БДІПЛ «Викладання тим голокосту і антисемітизму. Огляд і аналіз освітніх підходів» 2006 р. видане в рамках Програми БДІПЛ з толерантності та недискримінації при підтримці урядів Іспанії та США. Дослідження, серед іншого, визнає, що «погляди окремих педагогів, управлінь за освітою і педагогічних спілок можуть грати більш важливу роль, ніж погляд уряду», під час формування світогляду учнів та студентів. Констатується, що «викладачі повинні чутливо реагувати на почуття і погляди своїх слухачів» в рамках викладання гуманітарних дисциплін, таких як історія. В дослідженні містяться рекомендації про методики успішного викладу теми Голокосту для навчальних закладів, й підкреслюється «необхідність розробки спеціальних освітніх програм по боротьбі з сучасним антисемітизмом» [7].

Іншою важливою у вимірі стандартів вищої освіти є доповідь БДІПЛ «Протидія нетерпимості та дискримінації щодо мусульман: керівні принципи для викладачів. Боротьба з ісламофобією через освіту» 2011 р. Метою доповіді було визначене «надання працівникам освіти допомоги в боротьбі з нетерпимістю і дискримінацією стосовно мусульман»; керівні принципи стосувалися не лише викладачів, але й співробітників профспілок і професійних об'єднань педагогів, а також і членів неурядових організацій. Для збору інформації про дискримінацію пропонувалося здійснювати анонімне анкетування учнів та відзначалося, що таке «опитування можна проводити в рамках партнерства 3 дослідниками в галузі освіти, які працюють при університетах, в яких діють спеціальні правила проведення опитувань, що гарантують безпеку і анонімність». Також керівні принципи включали пропозицію включення тем про історію та культуру мусульман в освітні програми [8].
Питання забезпечення вищої освіти були, серед іншого, розкриті у «Керівних принципах з освіти в області прав людини для співробітників правоохоронних органів» БДІПЛ 2012 р. Цей документ був підготовлений за участі експертів Польської поліцейської академії в Шчітно, Шведської поліцейської академії, факультету правоохоронної діяльності Національного університету державної служби (Угорщина), Німецького поліцейського університету Мюнстер-Хілтрупу тощо. Керівні принципи грунтувалися на рішенні Ради міністрів ОБСС № 11/05 «Сприяння навчально-просвітницькій діяльності по тематиці прав людини в регіоні ОБСЄ» від 6 грудня 2005 р. У доповіді 2012 р. відзначалося, що пропоновані принципи можуть виявитися корисними в різних контекстах, наприклад, допомогти навчальним закладам, які здійснюють підготовку співробітників поліції, в розробці та перегляді відповідних навчальних програм і підходів до оцінки навчання [9].

Керівні принципи 2012 р. включають у себе шість основних розділів, які стосуються, відповідно, загальних положень та цілей, основних компетенцій, навчальних програм, включаючи принципи їх розробки, процеси підготовки та навчання, систему оцінювання, засади підготовки, підвищення кваліфікації та підтримки викладачів. Відповідні навчальні ресурси запропоновано розподілити на матеріали з викладання та навчання правам людини; матеріали про засновані на правах людини викладацькі підходи; матеріали з оцінки освіти в сфері прав людини. У принципах 2012 р. вказано, що навчальні курси для правоохоронних органів мають приділяти достатню увагу цінностям і нормам прав людини, що відповідний підхід поширюється і на роботу відповідних освітніх установ загалом [9].

Адже на виконання принципів в рамках своєї організаційної структури, процесів і процедур управління ці установи мають стверджувати такі принципи прав людини, як недискримінація і включення всіх, гідність і повагу, відповідальність держави за дотримання прав людини, участь та розширення можливостей всіх співробітників правоохоронних органів, що проходять навчання, а також всіх освітян. Керівні принципи 2012 р. передбачають дотримання установами освіти для правоохоронців принципів заохочення участі, самовираження, спілкування, співпраці та спільної роботи, із тим, щоб процеси підтримки дисципліни в установі не ображали людську гідність учнів і викладачів [9].

Наступною доповіддю БДІПЛ із відповідної проблематики стали «Керівні принципи 3 освіти в сфері прав людини для працівників охорони здоров'я» 2013 р., підготовлені фахівцями ОБСС у співпраці з Центром освіти в сфері прав людини Університету підготовки вчителів Центральної 
Швейцарії в Люцерні. У цих принципах відзначено, що права людини повинні стати частиною будь-якого навчання і будь-яких освітніх програм для всіх категорій медичних працівників. Документ передбачає, що освіта в галузі прав людини має доповнювати навчання медичному праву, медичній етиці та біоетиці, з урахуванням того, що ці курси «не можуть замінити собою навчання правам людини в програмах з підготовки працівників сфери охорони здоров'я» [10].

Керівні принципи 2013 р. були призначені, зокрема, для фахівців з підготовки медичного персоналу, викладачів медичних факультетів університетів та інших медичних навчальних закладів, розробників освітніх програм, а також для всіх інших зацікавлених сторін, що беруть участь у плануванні, реалізації та оцінці навчальних програм для працівників сфери охорони здоров'я. Як вказувалося у принципах, оскільки за освіту в галузі прав людини відповідають державні органи, очікується, що реалізація навчальних програм буде проходити в рамках відповідної політики в сфері освіти або на основі необхідної законодавчої бази, що має забезпечити стійкий характер освіти в сфеpi прав людини [10].

Наступний подібний документ БДІПЛ «Керівні принципи освіти в галузі прав людини для системи середньої школи» 2016 р., звісно, мав менше значення для вищої освіти. Водночас у ньому містяться вимоги до підготовки та перепідготовки педагогічних працівників для шкіл у галузі прав людини, а отже, відповідні стандарти діяльності вищих педагогічних навчальних закладів [4]. Варто додати, що БДІПЛ ОБСЄ проводить щорічні Наради з людського виміру, на яких представники держав-учасниць та неурядових організацій обговорюють різні аспекти захисту прав людини, включно зі складниками права на освіту. Водночас варіативність підходів держав ОБСЕ до прав людини, демократизації та освітньої діяльності призводить до обмежених практичних наслідків відповідних обговорень [11].

Крім ВКНМ та БДІПЛ, питання стандартів вищої освіти періодично підіймаються у місіях ОБСЕ в країнах-учасницях. Наприклад, Місія ОБСЄ в Сербії в грудні 2019 р. спільно з Сербським інститутом покращення освіти презентувала посібник з дисципліни «Громадянське виховання». Цей курс у Сербії читається з 2002 р. як у середній, так і у вищий школі з метою формування у студентів аналітичного та критичного мислення, ефективної участі в публічному житті та мирному співіснуванні демократичних суспільствах з культурним різноманіттям [14].

Водночас, як і структури ООН, ОБСЕ пішло шляхом утворення власного навчального закладу - Академії ОБСЄ у Бішкеку. Утворена в 2002 p. Академія ОБСЄ з самого початку концентрува- ла власну діяльність на шістьох азійських членах організації - Афганістані, Казахстані, Киргизстані, Таджикистані, Туркменістані та Узбекистані. Метою діяльності освітньої установи як «інституту, призначеному для просування принципів i цінностей ОБСЄ в Центральній Азії», було визначене «зміцнення регіонального співробітництва, запобігання конфліктів і забезпечення належного управління в Центральній Азії в рамках післядипломної освіти, професійної підготовки та інтелектуального обміну». Академія щорічно приймає до 60 студентів на конкурсній основі [6].

Правовий режим Академії ОБСЄ було визначено спеціальною двосторонньою угодою 2002 р. Меморандумом про взаєморозуміння між ОБСЄ та Урядом Киргизстану, що надав офіційний статус Академії як «регіонального центру післядипломної освіти та форуму для регіонального діалогу 3 питань безпеки та наукових досліджень» [13]. При цьому акредитація Академії як навчального закладу здійснюється за законодавством Киргизстану, а навчання здійснюється із «забезпеченням збалансованого представництва кожної держави Центральної Азії» [6].

32004 р. Академія ОБСЕ запустила свою основну програму, а саме - магістерську в області політології з акцентом на Центральній Азії; у 2011 р. була розпочата друга дипломована програма - магістерська за напрямом економічного управління та розвитку. 32010 р. випускники Академії за досягнутими домовленостями проходять стажування у міністерствах закордонних справ Киргизстану, Казахстану й Афганістану, а також й у Женевському центрі політичної безпеки та у Норвезькому інституті міжнародних відносин, ці дві освітні установи здійснюють й академічну підтримку закладу [6].

За таких умов з 2013 р. Академія ОБСЄ приєдналася до створеної Мережі аналітичних центрів та академічних установ ОБСЄ. Оскільки Академія ОБСЄ має статус юридичної особи національного права, для неї є важливою взаємодія з владою Киргизстану. Зокрема, в 2016 р. Міністерство юстиції цієї держави затвердило новий Статут Академії ОБСЄ в Бішкеку, схвалений Піклувальною радою Академії. Тоді ж, у 2016 р. на необмежений період часу був підписаний новий Меморандум про взаєморозуміння між ОБСє та Урядом Киргизької Республіки про подальшу діяльність Академії ОБСЄ в Бішкеку. Меморандум 2016 р. визначав у преамбулі Академію ОБСЄ в місті Бішкек як «унікальний центр освіти, підвищення кваліфікації, науково-дослідницької діяльності та розвитку діалогу на регіональному й міждержавному рівнях в Центральній Авії. Водночас завдання для Академії ОБСЄ цей Меморандум бачить у наданні освіти для молодих фахівців в сфері міжнародних відносин, безпеки, економічного розвитку та ме- 
неджменту, а також й у проведенні необхідних практичних досліджень 3 регіональних питань для зміцнення безпеки на національному та міждержавному рівнях [5].

За ст. 1 Меморандуму Академія ОБСЄ має керуватися ним, а також власним Статутом, у своїй діяльності в Киргизстані, де «загальний контроль» за діяльністю Академії, зокрема щодо внесення змін до іï освітніх програм, здійснюється киргизьким Міністерством освіти і науки, в рамках національного законодавства та за погодженням з ОБСЄ. Академія ОБСС за ст. 2 Меморандуму отримала право на проведення заходів згідно з мандатом Центру ОБСЄ в Бішкеку та на фінансування за рахунок внесків держав - учасниць ОБСЄ, а також і добровільних фінансових внесків інших внутрішніх та зовнішніх донорів [5].

Киргизстан, за ст. 3 Меморандуму зобов'язувався надати Академії ОБСС на безоплатній основі приміщення; сприяти Академії ОБСЄ з питань ліцензування та акредитації діяльності, а їі міжнародним співробітникам - отримати необхідну дозвільну документацію для роботи в країні. Також держава перебування зобов'язалася сприяти в отриманні віз іноземним студентам, викладачам, а також й співробітникам Академії ОБСС. Своєю чергою ОБСЄ за ст. 5 Меморандуму, в рамках роботи своїх представництв, Центрів в містах Бішкек, Астана, Ташкент, Ашхабад і Душанбе зобов'язувалася підтримувати реалізацію програм Академії в частині організації та мобілізації ресурсів, сприяти співпраці Академії ОБСЄ з вищими навчальними закладами Центральної Азії, регулярно інформувати держави регіону про плани та результати діяльності Академії ОБСЕ [5].

Для цього, за ст. 6 Меморандуму, ОБСЄ щомісяця представляє через Центр ОБСЄ в Бішкеку державам Центральної Азії звіти, що включають в себе перелік заходів, здійснених протягом звітного календарного місяця, інформацію щодо виконання цілей і завдань Академії ОБСС, аналіз і оцінку результатів реалізованих Академією заходів. Також Академія ОБСС щорічно в кінці академічного року подає Міністерству освіти і науки Киргизстану підсумковий звіт про свою діяльність [5].

Крім того, 1 квітня 2016 р. у розвиток цього договірного процесу було підписане Угоду про безоплатне використання державної нерухомості між Департаментом державних будівель при Адміністрації Президента Киргизстану і Академією ОБСЄ в Бішкеку. Варто додати, що Піклувальна рада Академії є її основним керівним та контролюючим органом, який складається з осіб, що виступають не у особистій якості, а як представники п'ятьох країн регіону, установ ОБСЄ та донорської спільноти; два члена ради представляють у ній власне Академію. До структури Академії ОБСЄ входить директор, його заступник, відділ з досліджень i тренінгів, відділ післядипломної освіти, міжнародний відділ, адміністративний та фінансовий відділ, магістерські програми «Політика і безпека» та «Економічне врядування та розвиток» [6].

Отже, підходи ОБСЄ до формування власного закладу вищої освіти мають певну специфіку, відмінну від підходів до цього питання ООН та установ системи ООН. Європейські стандарти вищої освіти зазнають вагомого розвитку через діяльність ОБСЄ, що реалізує власні завдання, як керуючись потребою забезпечення права на освіту, так й враховуючи значущість освіти для сталого співробітництва й безпеки. Не договірний характер самої ОБСЕ та участь в організації не лише європейських, але й усіх пострадянських та деяких інших держав зумовлює специфіку як охоплення, так й методів застосування стандартів ОБСЄ у сфері освіти. Основна увага в цих стандартах приділена захисту права меншин на освіту, запровадженню в рамках освіти анти-дискримінаційних механізмів, ефективному навчанню правам людини, зокрема й в рамках формальної вищої освіти різних кваліфікацій. Академія ОБСЄ в Бішкеку слугує специфічним прикладом реалізації наднаціональних практик ОБСЄ у сфері вищої освіти для конкретної установи. Реалізація стандартів ОБСЄ у сфері вищої освіти в Україні може слугувати підгрунтям для нових наукових досліджень.

\section{Jimepamypa}

1. Віденська декларація та Програма дій від 25 червня 1993 р. Законодавство України. URL: https://zakon.rada.gov.ua/laws/show/995 504 (Last accessed: 13.01.2020).

2. Гаазькі рекомендації щодо прав національних меншин на освіту і Пояснювальна записка. Жовтень 1996 p. Organization for Security and Co-operation in Europe. URL: https://www.osce.org/uk/hcnm/32194 (Last accessed: 13.01.2020).

3. Заключний акт Наради з безпеки та співробітництва в Свропі від 1 серпня 1975 р. Офіиійний вісник України. 2005. № 4. Ст. 266.

4. Керівні принципи освіти в галузі прав людини для системи середньої школи. Київ : BAITE, 2016. Organization for Security and Co-operation in Europe. URL: https://www.osce.org/uk/odihr/262226 (Last accessed: 13.01.2020).

5. Меморандум о взаимопонимании между Правительством Кыргызской Республики и Организацией по Безопасности и Сотрудничеству в Европе о дальнейшей деятельности Академии ОБСЕ в городе Бишкек: утвержден постановлением Правительства Кыргызской Республики от 15 июня 2016 г. № 316 Министерство юстиции Киргизстана. URL: http://cbd.minjust.gov.kg/act/ view/ru-ru/98534 (Last accessed: 13.01.2020).

6. Образование. Organization for Security and Cooperation in Europe. URL: https://www.osce.org/ru/ education (Last accessed: 13.01.2020).

7. Преподавание тем холокоста и антисемитизма. Обзор и анализ образовательных подходов: Бюро ОБСЕ по демократическим институтам и правам человека, 2006 г. Organization for Security and Co-operation in Europe. URL: https://www.osce.org/ru/odihr/18819 (Last accessed: 13.01.2020). 
8. Противодействие нетерпимости и дискриминации в отношении мусульман: руководящие принципы для преподавателей (Борьба с исламофобией через образование): Бюро ОБСЕ по демократическим институтам и правам человека, 2011 г. Organization for Security and Co-operation in Europe. URL: https://www.osce.org/ru/odihr/87759 (Last accessed: 13.01.2020).

9. Руководящие принципы по образованию в области прав человека для сотрудников правоохранительных органов. Бюро ОБСЕ по демократическим институтам и правам человека, 2012 г. Organization for Security and Co-operation in Europe. URL: https://www.osce.org/ru/odihr/98280 (Last accessed: 13.01.2020).

10. Руководящие принципы по образованию в области прав человека для работников сферы здравоохранения: Бюро ОБСЕ по демократическим институтам и правам человека, 2013 г. Organization for Security and Co-operation in Europe. URL: https://www.osce.org/ru/ odihr/109021 (Last accessed: 13.01.2020).

11. Свобода мысли, совести, религии и убеждений в РТ. Образование и религия: современное состояние и перспективы HDIM.DEL/0322/11 4 October 2011. Organization for Security and Co-operation in Europe. URL: https://www.osce.org/ru/odihr/83477 (Last accessed: 13.01.2020).

12. International Journal on Education Law and Policy. - Special Issue; Romania. - September 2004. Organization for Security and Co-operation in Europe. URL: https://www.osce.org/hcnm/78266 (Last accessed: 13.01.2020).

13. OSCE Academy Bishkek. Organization for Security and Co-operation in Europe. URL: http://www.osce-academy.net/(Lastaccessed:13.01.2020).

14. OSCE Mission to Serbia, Serbian Institute for Improvement of Education present manuals for civic education teachers. Organization for Security and Cooperation in Europe. URL: https://www.osce.org/ mission-to-serbia/441814 (Last accessed: 13.01.2020).

\section{Анотація}

Громовенко К. В. Право на вищу освіту в діяльності Організації з безпеки та співробітництва в Європі. Стаття.

У статті доведено, що наразі питання освіти у ОБСЄ опрацьовуються у декількох вимірах: захист освітніх прав меншин, освіта й права людини та освіта в умовах конфлікту. Автором підтверджено, що Бюро з демократичних інститутів і прав людини ОБСЕ серед іншого має на меті забезпечення поваги різноманітності і взаєморозуміння під час освіти та забезпечення освіти у сфері прав людини. У статті відображено увагу польових операцій ОБСЄ до освітніх питань щодо реформ системи освіти, включаючи юридичну освіту, визначення результатів і стандартів навчання, усунення дискримінації та відчуження під час освіти.

Автором досліджено Гаазькі рекомендації щодо прав національних меншин на освіту і Пояснювальну записку до них, методичні публікації ОБСє «Викладання тем голокосту і антисемітизму. Огляд і аналіз освітніх підходів» "Протидія нетерпимості та дискримінації щодо мусульман: керівні принципи для викладачів. Боротьба з ісламофобією через освіту», "Керівні принципи з освіти в сфері прав людини для співробітників правоохоронних органів» та «Керівні принципи з освіти в сфері прав людини для працівників охорони здоров'я».
Автором відзначено, що підходи ОБСЄ до формування власного закладу вищої освіти мають певну специфіку, відмінну від підходів до цього питання $\mathrm{OOH}$ та установ системи ООН. Європейські стандарти вищої освіти зазнають вагомого розвитку через діяльність ОБСЕ, що реалізує власні завдання, як керуючись потребою забезпечення права на освіту, так й враховуючи значущість освіти для сталого співробітництва й безпеки. Недоговірний характер самої ОБСЄ та участь в організації не лише європейських, але й усіх пострадянських та деяких інших держав зумовлює специфіку як охоплення, так і методів застосування спеціальних стандартів ОБСЕ у сфері освіти.

Основна увага в цих стандартах приділена захисту права меншин на освіту, запровадженню в рамках освіти анти-дискримінаційних механізмів, ефективному навчанню правам людини, зокрема й у рамках формальної вищої освіти різних кваліфікацій. Автором досліджено договірне, законодавче та статутне забезпечення діяльності власного навчального закладу організації Академії ОБСЄ у Бішкеку. У статті доведено, що ця Академія слугує специфічним прикладом реалізації наднаціональних практик ОБСЄ у сфері вищої освіти для конкретної установи. Автор резюмує, що реалізація стандартів ОБСЕ у сфері вищої освіти в Україні може слугувати підгрунтям для нових наукових досліджень.

Ключові слова: викладання прав людини, вища освіта, ОБСЕ, освіта меншин, право на освіту.

\section{Summary}

Gromovenko $K$. V. Right to higher education in the activities of the Organization for Security and Co-operation in Europe. - Article.

The article argues that OSCE education standards are currently being addressed in several dimensions, such as the protection of minority educational rights, education and human rights, and education in conflict. The author reaffirms that the OSCE Office for Democratic Institutions and Human Rights, among other things, aims to ensure respect for diversity and understanding in education and human rights education. The article reflects the focus of OSCE field operations on educational reform issues, including legal education, defining educational outcomes and standards, issues of the eliminating discrimination and alienation during education.

The author explores the OSCE High Commissioner's on National Minorities Hague Recommendations on the Education Rights of National Minorities and the Explanatory Note to them, also as relevant OSCE methodical publications such as "Education on the Holocaust and on Anti-Semitism: An Overview and Analysis of Educational Approaches", "Guidelines for Educators on Countering Intolerance and Discrimination against Muslims: Addressing Islamophobia through Education", "Guidelines on Human Rights Education for Law Enforcement Officials" and "Guidelines on Human Rights Education for Health Workers".

The author noted that the OSCE's approaches to the formation of its own institution of higher education have some specificity, different from the approaches to this issue of the UN and institutions of the UN system. European higher education standards are undergoing significant development through the work of the OSCE, which accomplishes its own tasks, both in the light of the need to ensure the right to education and in view of the importance of education for sustainable cooperation and security. The non-contractual nature of the OSCE itself, and participation in the organization of not only European but 
also all post-Soviet and some other States, determines the specifics of both coverage and methods of applying OSCE standards in the field of education.

The focus of these standards is on the protection of the right of minorities to education, the introduction of anti-discrimination mechanisms in education, effective human rights education, and in particular in the formal higher education of various qualifications. The author investigates the contractual, legislative and statutory sup- port of the OSCE's own educational institution in Bishkek. The article argues that this Academy is a specific example of the implementation the supranational higher education practices by OSCE for a particular institution. The author summarizes that the implementation of OSCE standards in higher education in Ukraine can serve as a basis for new scientific research.

Key words: human rights education, higher education, minority education, right to education, OSCE. 